\title{
KOHTI AUDIOVISUAALISIA JA YHTEISKUNNALLISIA UTOPIOITA
}

\author{
Heta Mulari
}

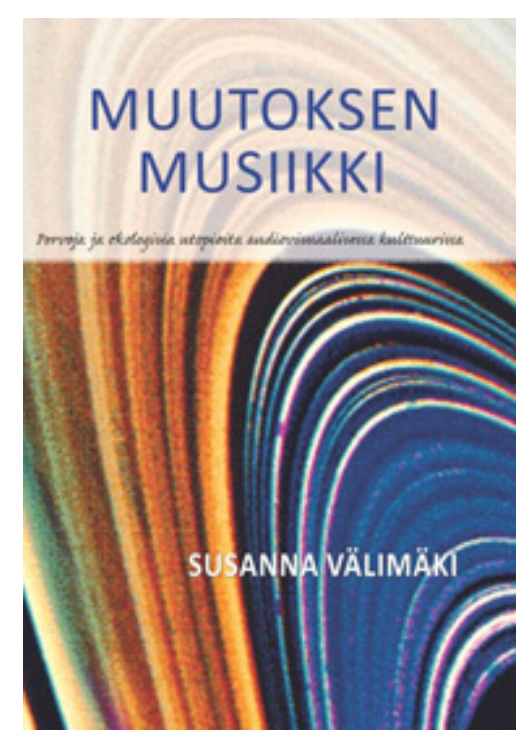

Susanna Välimäki. 2015. Muutoksen musiikki: Pervoja ja ekologisia utopioita audiovisuaalisessa kulttuurissa. Tampere: Tampere University Press, 339 s.

Susanna Välimäki aloittaa teoksensa Muutoksen musiikki: Pervoja ja ekologisia utopioita audiovisuaalisessa kulttuurissa kuvaamalla vakuuttavasti sitä, kuinka taidekokemus voi parhaimmillaan vaikuttaa perustavanlaatuisella tavalla ihmisen olemassaoloon. Pysäyttävä elokuva, näyttely, kirja tai musiikki voi jäsentää ihmisen ajatusmaailmaa uudelleen ja laittaa hänet liikkeeseen. Ihmisen ja taideteoksen välille syntyy kohtaaminen, jossa syntyy uutta; pientä ja suurta kumouksellisuutta.

Välimäki käyttää tutkimuksessaan käsitettä muutoksen taide, jolla hän viittaa taiteen potentiaaliin kyseenalaistaa valmiita ajatuksia, hyväksyttyjä totunnaisuuksia ja lukkoon lyötyjä merkityksiä. Muutoksen taide voi toimia maailmaa ja elämää uudelleen jäsentävänä voimana, joka synnyttää hetkellisiä utopian kokemuksia, jotka voivat sekä tuoda näkyväksi valta- kulttuurin lukkiutuneita käytänteitä ja ajatusrakennelmia että horjuttaa niitä paikoiltaan. Muutoksen taide viittaa sekä kumouksellisiin teoksiin että lukutapoihin, joiden avulla on mahdollista haastaa ja hämmentää valtakulttuurin itsestäänselvyyksinä näyttäytyviä rakenteita.

Muutoksen musiikki paikantaa audiovisuaalisesta nykytaiteesta - televisiosarjasta Angels in America (2002), elokuvista Transamerica (Duncan Tucker 2005), Tunnit (Stephen Daldry 2002), Uusi maailma (Terrence Malick 2005) ja Elämän puu (Terrence Malick 2011) sekä teatteriesityksestä Tuntematon sotilas (Kristian Smeds 2007-2009) - utopioita, eli paikkoja ja tuokioita, jotka horjuttavat vallitsevaa heteronormatiivista, uusliberalistista ja konservatiivista järjestystä. Välimäki tulkitsee näitä teoksia queer- ja transtutkimuksen sekä ekomusikologian kautta. Näitä tutkimussuuntauksia yhdistää ajatus toisin kuuntelemisesta. Välimäki ymmärtää käsittelemänsä audiovisuaaliset aineistot utopian tiloina, jotka voivat yhtäl̈lä horjuttaa heteronormatiivista järjestystä ja toisaalta käsitteellistää uudelleen ihmisen ja luonnon välistä suhdetta niin, että ihmisen itsestään selvänä pidetty valta-asema luontoon nähden kyseenalaistuu.

Tutkimus jakaantuu käsittelylukuihin, joista kukin avaa yhtä audiovisuaalista nykytaideteosta tietyn käsitteen kautta. Näitä ovat homous, transsukupuoli, elämä, kuolema, luonto ja kansa. Pidän tätä käsittelytapaa tutkimuksen erityisenä ansiona, sillä käsitteiden kautta kukin audiovisu- 
aalinen aineisto avautuu sekä sisältöanalyyseille että filosofis-teoreettisille pohdinnoille toisin kuuntelemisen näkökulmasta. Olen tässä arviossa valinnut tarkempaan käsittelyyn kirjan luvut "Elämä”, jossa käsitellään Tunnit-elokuvaa, ja "Kansa", jossa pureudutaan Tuntemattomaan sotilaaseen.

\section{Kuullut Tunnit}

Stephen Daldryn ohjaama ja Michael Cunninghamin romaaniin perustuva elokuva Tunnit paikantuu Virginia Woolfin Mrs Dalloway -romaanin ympärille, ja se kietoutuu monisukupolvisiin naiseuden ja ei-heteroseksuaalisuuden teemoihin. Kaikkia elokuvan keskeisiä hahmoja yhdistää queer-identiteetti. Välimäki liittää Tunnit osaksi 1990-luvun lopun ja 2000-luvun alun ilmiötä, jossa seksuaali- ja sukupuolivähemmistöjen kuvaus valtavirran audiovisuaalisessa kulttuurissa laajeni selvästi. Queerkulttuuri ja valtakulttuuri kohtasivat ja sekoittuivat eri tavalla kuin ennen, ja queer-näkökulma tuli osaksi valtakulttuurin kuvastoja, kuten elokuvia ja televisiosarjoja. Tämä "queer-muodikkuus" on herättänyt myös kritiikkiä ja pelkoa siitä, että vastakulttuurinen sanoma menettää terävimmän kriittisyytensä lomittuessaan osaksi vallitsevaa uusliberalistista kulttuuria. Myös siksi kriittiset queer-luennat näistä teksteistä ovat erityisen tärkeitä.

Itselleni kulttuurihistorioitsijana Tunnit on aina ollut kiehtova, ajatuksia vavahduttava elokuva. Useamman kerran elokuvan nähtyäni olen kiinnittänyt huomiota siihen, kuinka ajan kuluminen on läsnä tietyssä hetkessä, kuinka aika on kudoksellista ja historia kerroksellista. Naisen melankolian, oman huoneen, feministisen liikkeen ja epänormatiivisen seksuaalisuuden historia on läsnä yhtä aikaa Mrs Dalloway -romaania kirjoittavan Virginia Woolfin kirjoituspöydälle pinotuissa paperiarkeissa, 1950-luvun kotirouva Laura Brownin syvässä masentuneisuudessa, jota hän yrittää epätoivoisesti paeta omaa huonetta etsien sekä newyorkilaisen kustannustoimittaja Clarissa Vaughanin kipeässä hoivasuhteessa pitkälle edennyttä aidsia sairastavaan nuoruudenrakastettuunsa Richard Browniin.

Elokuvassa aika virtaa hetkestä ja vuosikymmenestä toiseen keskeisen vesielementin tavoin, ja saa samalla kriittisesti kyseenalaistamaan ja pohtimaan sitä, kuinka kirjoitamme historiaa. Kuinka kerromme henkilökohtaista historiaamme tai toisten ihmisten, teemojen tai yhteiskunnallisten ilmiöiden historiaa - mitä teemoja ja tapahtumia valitsemme kerrottaviksemme? Kuten Välimäki toteaa, Tunneissa lineaarinen, länsimainen aikakäsitys murtuu ja rikkoutuu, ja aikaa tarkastellaan tajunnanvirtamaisella, woolfmaisella tekniikalla. Yksi yksittäinen historiallinen totuus murtuu, ja sen sijaan astuu eri ihmisten rinnakkaisia, sisäisiä, hetkistä muodostuvia totuuksia, jotka lomittuvat toisiinsa yllättävillä ja murroksellisilla tavoilla - historiaa kirjoitetaan queer-näkökulmasta, joka avaa vastakerronnan paikkoja.

Välimäen tutkimus avasi itselleni näkökulman, joka oli jäänyt minulta aiemmin pitkälti huomiotta elokuvaa katsoessani. Nimenomaan katsoessani, sillä jo tämä ilmaisu kiteyttää konventionaalisen suuntautumiseni elokuvaan. Paikantaessaan elokuvan musiikki- ja äänimaisemasta elementtejä, jotka horjuttavat suoraviivaisia konventioita ja heteronormatiivista järjestystä, Välimäki nostaa analyysissaan esiin sen, kuinka elokuvaa voi katsomisen ohella kuunnella queer-korvalla. Hän kuvaa elokuvaa "poikkeuksellisen soivana elokuvana" (s. 133), jossa pitkät musiikkikatkelmat ja toistuvat äänielementit muodostavat virran, joka sitoo paitsi elokuvan kohtaukset, myös keskeiset henkilöhahmot ja ajalliset kerrostumat toisiinsa. Esimerkkinä näistä äänielementeistä on kellon tikitys, joka on läsnä samaan aikaan kaikkien päähenkilöiden arjessa kuvastaen ajan ja elämänkulun vääjäämättömyyttä. Elokuvan pianomusiikkia voi puolestaan kuulla ja tulkita utopian tilana, joka ilmentää kaikkien keskeisten hahmojen jatkuvaa

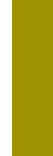


muutosta ja elämän virtaavuutta hetkestä toiseen. Musiikki on näin ollen oleellinen lineaarista aikakäsitystä ja eheää, koherenttia subjektikäsitystä nyrjäyttävä tekijä.

\section{Yhteiskunnallisia nyrjähdyksiä}

Tutkimuksen viimeisessä alaluvussa Välimäki tarkastelee Kristian Smedsin Suomen kansallisteatterille vuonna 2007 ohjaamaa Tuntematonta sotilasta. Näytelmä sai aikaan mediakohun ja kritiikkiä erityisesti lopun ampumakohtauksesta, jossa kankaalle heijastetut merkkihenkilöt ja satuhahmot ammuttiin ja räjäytettiin äänimaiseman saattelemina. Kuten Välimäki toteaa, kohtauksen aikaansaama kritiikki toi näkyväksi sen, kuinka tavallisten, tuntemattomien kansalaisten tai Irakin sodan uhrien surmaaminen näytöksessä ei herättänyt lähimainkaan samanlaista kritiikkiä kuin merkkihenkilöiden. Tämä osoittaa, kuinka taide voi tehdä näkyväksi yhteiskunnallisia valtasuhteita ja vallitsevia normatiivisia käsityksiä.

Välimäki liittää Tuntemattoman sotilaan osaksi niin sanottua postmodernia teatteria, jossa irrottaudutaan perinteisestä draamateatterista ja ammennetaan moniaistisesta ja monimediaisesta esitystaiteesta, joka pyrkii tietoisesti rikkomaan taiteenlajien ja esitystapojen rajoja. Postmoderni teatteri on lähtökohtaisesti kriittistä ja analyyttista itseään kohtaan ja reflektoi omia esitystapojaan, konventioitaan ja poliittisia ja yhteiskunnallisia pyrkimyksiään.

Välimäki kutsuu Tuntemattoman esitystapaa audiovisuaaliseksi rytmiksi, joka muodostui itsenäisistä, esityksellisistä toimintablokeista ja niitä yhdistävistä audiovisuaalisista vaihdoksista. Nämä monimediaiset vaihdokset koostuivat musiikista, valoista, kuvista, näyttämöasetelmista ja erilaisten tilaratkaisujen muutoksista. Välimäki nostaa esiin tärkeällä tavalla sen, kuinka näiden audiovisuaalisten valintojen kautta näytelmää päästiin laa- jentamaan ulos lavalta yleisöön. Teatteritilan laajentaminen moniaistisin ja monimediaisin keinoin johti myös siihen, että esityksen tematiikasta ja yhteiskuntakritiikistä tuli jaettua. Kuten Välimäki toteaa: "Kaikki tämä viesti, että esityksessä oli kyse "meistä", yhteisistä asioista, yhteiskunnasta, jaetusta maailmasta." (s. 251) Ja laajemmin, Tuntemattoman siirtäminen 2000-luvulle merkitsee myös sodan päivittämistä globaaliksi, ongelmien näkemistä yleismaailmallisina ja vanhojen kertomusten ja isänmaallisten symbolien nyrjäyttämistä uudesta näkökulmasta. Esityksen kautta hahmottui uusi tila ekokeskeisestä ja monikulttuurisesta yhteiskunnasta. Välimäen luennassa Smedsin Tuntematon on näin ollen puhtaimmillaan nyrjäyttävää ja kiistävää muutoksen taidetta, jolle näen itse vertauspintoja muun muassa Ryhmäteatterin Eduskunta-trilogiassa.

\section{Muutoksen tutkimusta?}

Kuten Välimäki toteaa, sekä musiikin queer-tutkimus että ekomusikologia, joka kytkeytyy ajatukseen ekokeskeisemmästä yhteiskunnasta, jossa ihmisen valta-asema kyseenalaistuu, liittyvät tutkimuspoliittiseen pyrkimykseen saada aikaan muutosta. Elämme yhteiskunnassa, jossa tarvitaan sekä taiteellisia että tieteellisiä utopioita.

Muutoksen taide voikin olla yksi avain muutokseen, joka voi toimia yhtä aikaa henkilökohtaisena sekä yhteiskunnallisena liikuttajana. Taide-elämyksen kohtaaminen oikealla hetkellä voi saada aikaan yllättäviä murtumia - itselleni näin kävi kun törmäsin australialaisen taiteilijan Sia Furlerin nykytanssista ammentavaan musiikkivideotrilogiaan Chandelier, Elastic Heart ja Big Girls Cry (2014-2015). Tutustuttuani näihin kappaleisiin ja musiikkivideoihin löysin itseni kyseenalaistamassa käsitystäni tiedon tuotannosta ja sen väistämättömästä kehollisuudesta, pohtimassa tyttöyttä posthumanistisesti sekä esiintymisen ja katseen politiikkaa uudesta näkökulmasta. Tämän lisäksi löysin konkreettisesti itseni tanssitunneilta. Taide 
sai aikaan muutoksen, liikahduksen ja nyrjähdyksen niin henkilökohtaisella kuin teoreettisella ja tiedontuotantoon liittyvillä tasoilla.

Muutoksen musiikki herätti ajattelemaan tieteellisen tutkimuksen ja kirjoittamisen utopioita. Kuinka voimme kirjoittaa kumouksellisesti ja millä keinoin voisimme horjuttaa tieteellisen kaanonin rajoituksia niin, että muutos akatemian sisällä olisi myös mahdollista? Millaista voi olla muutoksen tutkimus, ja onko tutkijoilla tässä opittavaa taiteen kumouksellisuudesta? Jäin miettimään tutkijoiden mahdollisuuksia tehdä tutkimuspoliittisia avauksia - paitsi nostamalla esiin tutkimuksissaan vaikuttavia ja horjuttavia ilmiöitä sekä lukemalla valtakulttuurin ilmiöitä vastakarvaan - myös tekemällä itse, akatemian sisällä, sen nykyistä uusliberaalia suuntaa horjuttavia konkreettisia tekoja. Tämä voi tarkoittaa myös tutkijoiden astumista erilaisiin utopian tiloihin, joissa pyritään nyrjäyttämään akateemisen maailman sisäisiä hierarkioita. 